\title{
STUDIES ON THE EXISTING STATE OF VITAMIN A IN FISH LIVER AND OTHER ORGANS I
}

\author{
YAROKURO YAMAMURA \\ Tohoku Regional Fisheries Research Laboratory, Shiogama, Miyagi-ken.
}

(Received April 2, 1956)

For visualizing vitamin $\mathrm{A}$ in the tissues of man and animals, fluorescence microscopy was employed by Querner (1), Hirt (2), Wimmer (3) and Popper (4), etc. Carr-Price method by Joyet-Lvergne (5), and glycerol dichlorohydrin (GDH) method introduced by Feinstein (6) and Sobel and Werbin (7), was applied by Katsui (8) and Araki (9). The latter authors have studied the existing state of vitamin A in fish organs such as the pyloric caeca of the scomber or pollack. But no paper dealing with the manner, in which vitamin A exists in fatty organs such as the liver of the dog fish (Squalus sucklyi), has been available to the author.

In the present paper the results of the experiment are reported, concerning the mode of distribution of vitamin A in the liver, pyloric caeca, intestine and other organs of several kinds of fish, especially the oil sole and dog fish which reveal the existence of much vitamin A by histochemical research.

\section{EXPERIMENTAL}

\section{Methods}

Staining of Fat A hematoxylin staining method using paraffin sections (10) was employed. In preparing paraffin sections fat and vitamin A are eliminated by alcohol, and the site of oil globules is detected as transparent spots.

Staining of Vitamin A-GDH reagent prepared by Fujita and Aoyama's method (11) as well as Carr-Price reagent were used after the fat substance had been fixed with osmic acid in the frozen section of the liver and other organs.

\section{Results}

1. The Relations Between the Oil and Vitamin A Contents and the Coarseness of Tissues.

Paraffin sections of the tissues of several kinds of fish, e.g., the liver and pyloric caeca of the oil sole (Athresthes evermenni J. et S.), the liver, kidney and spleen of the dog fish (Squalus suckleyi G.), the liver of the blue shark (Prionace glauca L.), salmon shark (Lamna cornubica Gmelin), thunny (Thunnus 
orientalis T. et S.), coral rock fish (Sebastodes sp.), skip jack (Katsuwonus pelamis Linnaeus), and pollack (Theragra chalcogramma Pallas) were prepared. Some representative are shown in Fig. 1.

In lean tissues, such as the livers of the oil sole and coral rock fish, the small colorless spots corresponding to oil globules are observed, while in fatty tissues, such as the livers of the pollack, dog fish and blue shark, fat is retained in the networks of protein-like substances, namely lattice fibre (12). Nucleus are also observed smong these lattice fibres.

Particularly, melanophores as large as $2-5 \mu$ are dispersed in the liver of the dog fish which may possibly be the cause of the "dark-colored livers", as shown in Fig. 1 (6).

In the livers of the skipjack or tunny (Fig. 1(3)) which are of very lean tissues it is observed that the striped patterns of very compact layers and comparatively coarse layers of the protein substances exist alternatively when stained with hematoxylin or Malory's dyes.

In salmon shark liver, the middle part being as coarse as that of the dog fish and blue shark, is discriminative from the marginal part which is as compact as the liver of the thunny (Fig. 1). That is to say, the liver tissues of the skipjack, tunny, salmon shark (marginal part) resemble those of mammals, e.g., the pig, consisting mainly of non-fatty tissues, while those of the dog fish, blue shark and slmon shark (middle part), consist mainly of fatty tissues having the nature of adipose tissue (12). Those of the pollack are largely the same. In other organs, such as the kidney and spleen of the dog fish and the pyloric caeca and intestine of the oil sole, the existing states of fat were also observed. The kidney of the dog fish consist of an aggregation of tubular tissues. The spleen, however, appeared to consist of homogeneous protein-like substances. They are lean tissues in general.

In Table I, the relations between the oil and vitamin A contents (estimated chemically) and the coarseness of the tissues of these fish are listed. These findings are summarized as follows:

Generally speaking, tissues containing a large amount of oil are coarse, and low in vitamin A units except the liver of the dog fish and blue shark, while the tissues containing little oil are compact and high in vitamin A units, especially in the pyloric caeca of the oil sole.

The mean differences between the maximum and minimum vitamin A units of oil are several times, but some reach as large as 50-100 times as in the case of the pyloric caeca of the oil sole or the kidney and spleen of the dog fish, possibly indicating that the vitamin A levels in tissues rise or fall according to seasonal or physiological conditions.

The fluctuations of vitamin A contents per $\mathrm{g}$ of tissue in various species and organs are, as shown in Table I, much smaller in quantity than those per $\mathrm{g}$ of oil. The former figures may possibly serve as a measure of the capacity of the tissue to preserve vitamin A.

According to this presumption, the viscera of the oil sole have the property of preserving more vitamin A than the liver, whereas the liver of the dog fish preserves more vitamin A than the kidney and spleen. In the sal- 
Non-Fatty Tissues

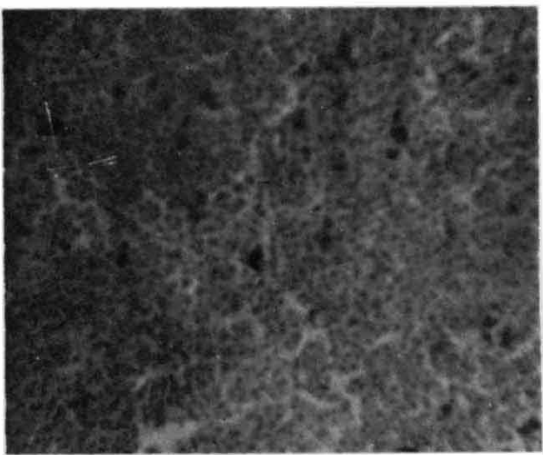

1. Liver (margin) of a salmon shark. $(\times 200)$

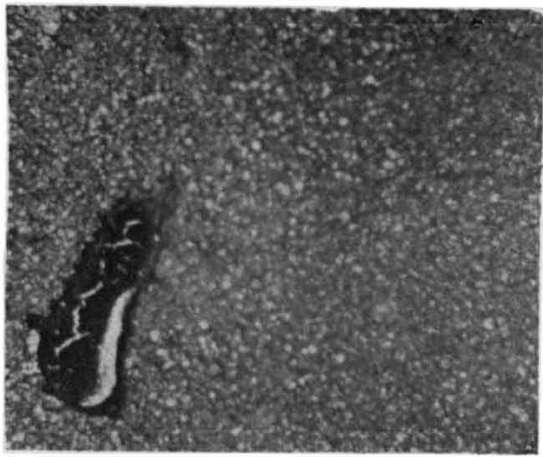

2. Liver of a caral rock fish. $(\times 200)$

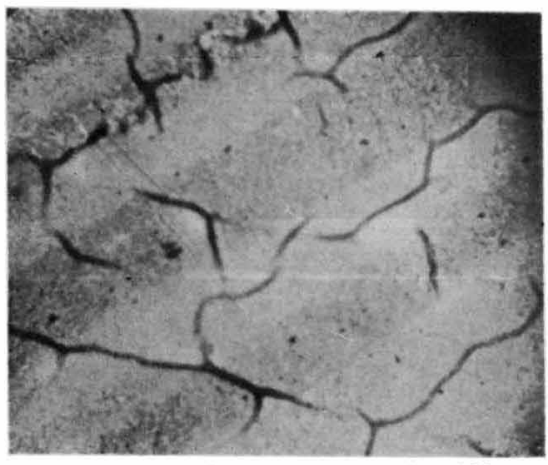

3. Liver of a thunny. $(\times 200)$
Fatty Tissues

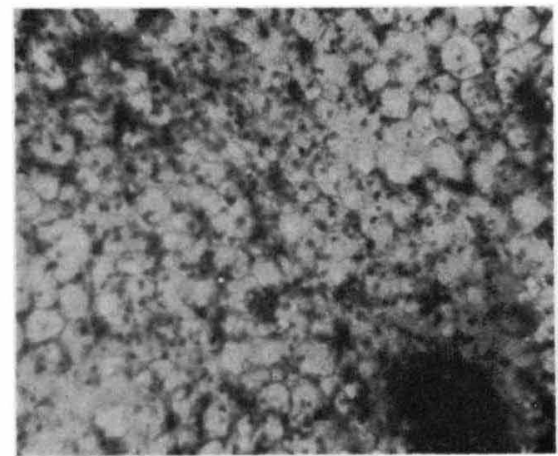

4. Liver (middle) of a salmon shark. $(\times 200)$

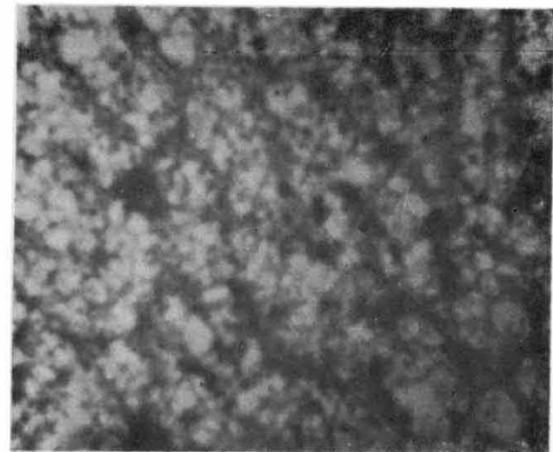

5. Liver of a blue shark.

$(\times 200)$

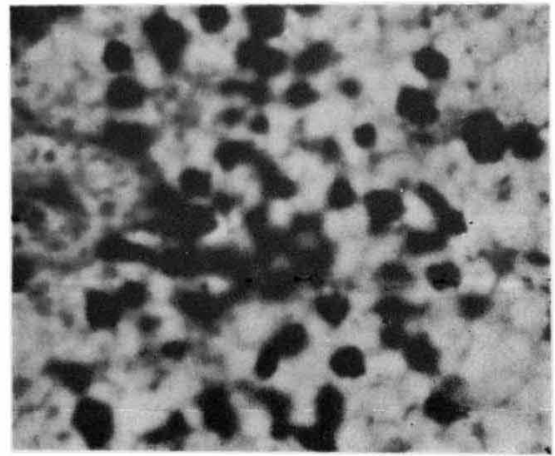

6. Dark liver of a dog fish.

$(\times 400)$

Fig. 1.

Histological View of the Existing State of Fat in Some Fish Livers.

(Paraffin sections stained with hematoxylin). 


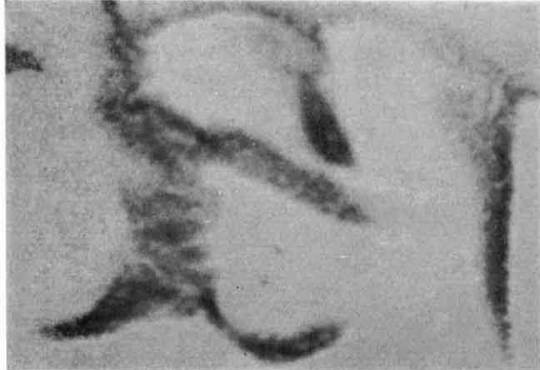

1. Pyloric caeca of an oil sole, control. $(\times 100)$

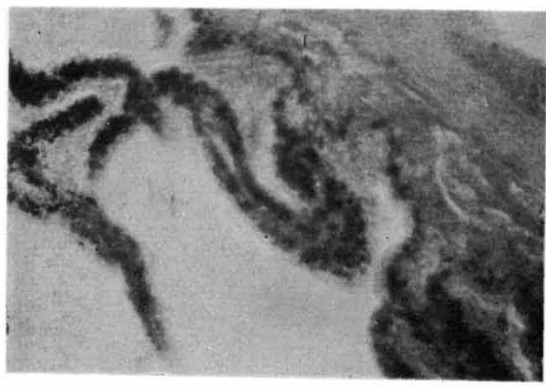

2. Pyloric caeca of an oil sole, fixed with osmic acid.

$(x 100)$

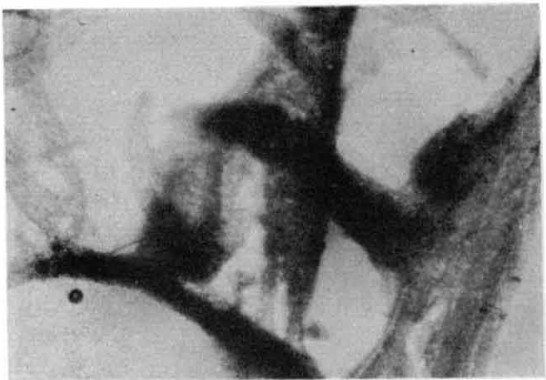

3. Pyloric caeca of an oil sole, stained with GDH after osmic acid fixation.

$(\times 200)$

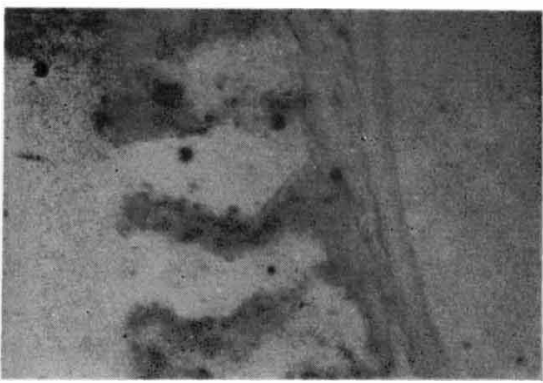

4. Pyloric caeca of an oil sole, stained with GDH.

$(\times 200)$

Fig. 2

The Microscopic Views of the Existence of Vitamin $A$ in the Pyloric Caeca of an Oil Sole, Visualized by Means of Osmium-GDH Method. (Frozen sections)

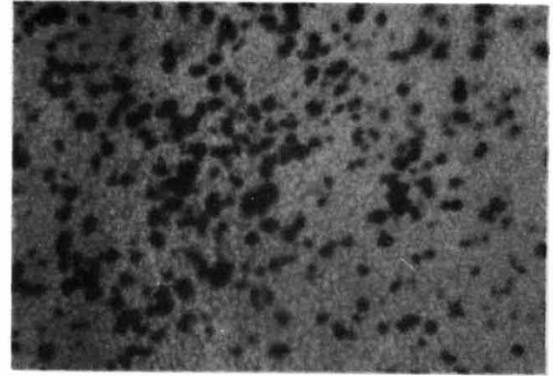

1. Liver of a dog fish, immersed in $99 \%$ alcohol, control.

$(\times 200)$

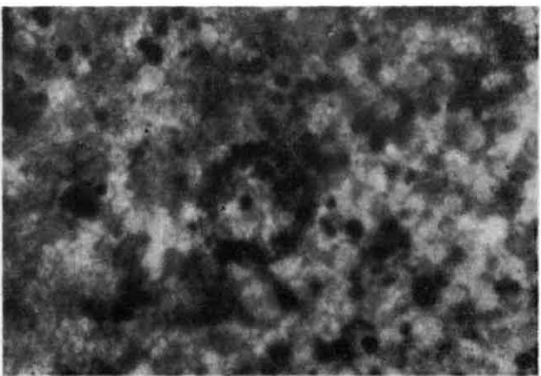

2. Liver of a dog fish, stained with Os-GDH after immersion in $99 \%$ alcohol for 15 minutes. $(\times 200)$

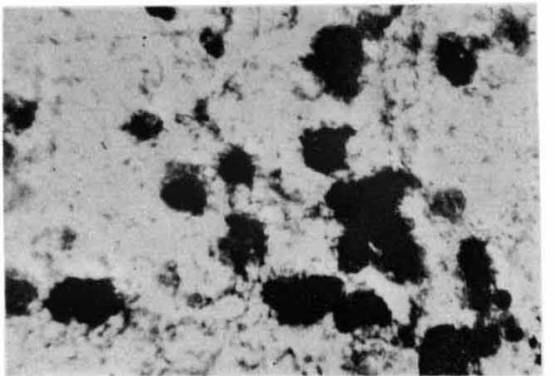

3. Liver of a dog fish, defatted by heating with water, control.

$(\times 315)$

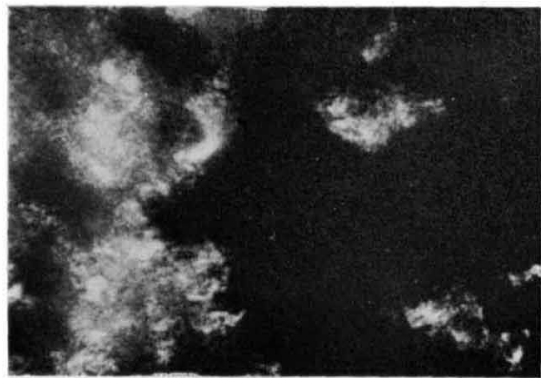

4. Liver of a dog fish, defatted by heating with water and then stained with Carrprice reagent.

$(\times 315)$

Fig. 3

The Microscopic Views of the Existence of Vitamin A in Pyloric Caeca of an Oil Sole, Visvalized by Osmium-GDH Method. (Frozen section). 
TABLE I

The Relationship between Oil and Vitamin A Contents and Coarseness of the Tissues of the Liver and Other Organs of Several Species of Fish.

\begin{tabular}{|c|c|c|c|c|c|c|c|}
\hline & $\begin{array}{l}\text { Body } \\
\text { length }\end{array}$ & $\begin{array}{l}\text { Oil } \\
\text { content }\end{array}$ & $\begin{array}{l}\text { Vitamin } \\
\text { Mean }\end{array}$ & Maximum & $\begin{array}{l}\text { (pergoil) } \\
\text { Minimum }\end{array}$ & $\begin{array}{l}\text { V. A } \\
\text { Content } \\
\text { per g } \\
\text { tissue }\end{array}$ & Coarseness \\
\hline $\begin{array}{l}\text { Oil sole } \\
\text { Liver } \\
\text { Viscera }\end{array}$ & $\begin{array}{c}\mathrm{cm} \\
40-70\end{array}$ & $\begin{array}{l}\text { per cent } \\
\\
32 \\
3.4\end{array}$ & $\begin{array}{r}8,000 \\
270,000\end{array}$ & $\begin{array}{r}72,000 \\
900,000\end{array}$ & $\begin{array}{l}2,000 \\
8,000\end{array}$ & $\begin{array}{l}2,550 \\
9,200\end{array}$ & Dense \\
\hline $\begin{array}{l}\text { Dog fish } \\
\text { Liver } \\
\text { Kidney } \\
\text { Spleen }\end{array}$ & $\begin{array}{c}60-110 \\
(70-102)\end{array}$ & $\begin{array}{r}62 \\
3.9 \\
4.9\end{array}$ & $\begin{array}{r}6,500 \\
12,000 \\
5,700\end{array}$ & $\begin{array}{l}46,000 \\
60,000 \\
27,000\end{array}$ & $\begin{array}{l}800 \\
500 \\
600\end{array}$ & $\begin{array}{r}4,050 \\
470 \\
260\end{array}$ & $\begin{array}{l}\text { Coarse } \\
\text { Dense } \\
\text { Dense }\end{array}$ \\
\hline $\begin{array}{l}\text { Blue shark } \\
\text { Dark liver } \\
\text { Light liver }\end{array}$ & $100-180$ & $\begin{array}{l}40 \\
50\end{array}$ & $\begin{array}{r}40,000 \\
2,000\end{array}$ & $\begin{array}{r}53,000 \\
4,000\end{array}$ & $\begin{array}{r}20,000 \\
800\end{array}$ & $\begin{array}{r}16,000 \\
1,000\end{array}$ & $\begin{array}{l}\text { Coarse } \\
\text { Coarse }\end{array}$ \\
\hline $\begin{array}{l}\text { Salmon shark } \\
\text { Middle } \\
\text { Margin }\end{array}$ & $120-170$ & $\begin{array}{l}53 \\
15\end{array}$ & $\begin{array}{r}2,000 \\
23,000\end{array}$ & $\begin{array}{r}5,000 \\
50,000\end{array}$ & $\begin{array}{r}400 \\
4,000\end{array}$ & $\begin{array}{l}1,060 \\
3,450\end{array}$ & $\begin{array}{l}\text { Coarse } \\
\text { Dense }\end{array}$ \\
\hline $\begin{array}{l}\text { Coral rock fish } \\
\text { Liver }\end{array}$ & $38-48$ & 15.5 & 54,000 & 235,000 & 45,000 & 8,400 & Dense \\
\hline Skipjack, liver & ca. & 10 & 20,000 & 30,000 & 10,000 & 2,000 & Dense \\
\hline Thunny, liver & ca. 60 & 5 & 30,000 & - & - & 1,500 & Dense \\
\hline $\begin{array}{l}\text { Pollack } \\
\text { Liver } \\
\text { Pyloric caeca }\end{array}$ & $40-60$ & $\begin{array}{l}35 \\
2.2\end{array}$ & $\begin{array}{l}5,000 \\
4,700\end{array}$ & $\begin{array}{r}15,000 \\
6,500\end{array}$ & $\begin{array}{r}700 \\
3,000\end{array}$ & $\begin{array}{r}1,750 \\
104\end{array}$ & $\begin{array}{l}\text { Somewhat } \\
\text { dense }\end{array}$ \\
\hline
\end{tabular}

mon shark, the marginal part of the liver selectively preserves more vitamin A than the middle part, while in the pollack, the liver preserves more vitamin A than the pyloric caeca.

The capacity of preserving vitamin A also depends on the colour of the liver, $i . e$, dark $>$ light in case of the blue shark and dog fish.

Considering this relation in detail, and taking the dog fish as an example, as indicated in Table II, the order of the vitamin A-preserving capacity is as follows:

Dark-colored liver $>$ medium-colored liver (omitted in the Table) $>$ lightcolored liver.

Basal part $>$ middle or terminal part.

Middle lobe $>$ right or left lobe.

The relation between the vitamin A-preserving capacity and the property of the tissue was found to be as follows:

In livers rich in vitamin A - The tissue is dense containing numerous melanin pigments;

In livers poor in vitamin A - The tissue is coarse containing little melanin pigments.

2. The Existing State of Vitamin A.

Vitamin $A$ in the Pyloric Caeca and Intestine of the Oil Sole-Frozen sections of tissues, when fixed in osmic acid for a short time, show a bluish- 
TABLE II

Oil and Vitamin A Contents of Dog Fish Liver in regard to Color, and Parts as well as Coarseness and Density of Melanin Pigments of the Tissue.

\begin{tabular}{|c|c|c|c|c|c|}
\hline & $\begin{array}{l}\text { Oil } \\
\text { content }\end{array}$ & $\begin{array}{l}\text { Vitamin } A \\
\text { per } g \text { oil }\end{array}$ & $\begin{array}{l}\text { oncentration } \\
\text { per } g \text { tissue }\end{array}$ & $\begin{array}{l}\text { Coarsness } \\
\text { of tissue }\end{array}$ & $\begin{array}{l}\text { Density of } \\
\text { melanin pigments }\end{array}$ \\
\hline Left lobe & \multicolumn{5}{|c|}{$\begin{array}{lll}\text { per cent } & \text { I. U. } \\
& \text { Dark-coloured liver }\end{array}$} \\
\hline $\begin{array}{l}\text { End } \\
\text { Middle } \\
\text { Base }\end{array}$ & $\begin{array}{l}59.5 \\
67.0 \\
61.5\end{array}$ & $\begin{array}{l}26,500 \\
22,800 \\
34,000\end{array}$ & $\begin{array}{l}15,800 \\
15,200 \\
21,000\end{array}$ & $\begin{array}{l}\text { Coarse } \\
\text { Coarse } \\
\text { Dense }\end{array}$ & $\begin{array}{l}t \\
+t \\
+t\end{array}$ \\
\hline Central lobe & 50.5 & 57,000 & 28,800 & Dense & +++ \\
\hline $\begin{array}{l}\text { Right lobe } \\
\text { End } \\
\text { Middle } \\
\text { Base }\end{array}$ & $\begin{array}{l}60.5 \\
64.0 \\
54.0\end{array}$ & $\begin{array}{l}30,500 \\
26,500 \\
45,500\end{array}$ & $\begin{array}{l}18,400 \\
17,000 \\
24,500\end{array}$ & $\begin{array}{l}\text { Coarse } \\
\text { Coarse } \\
\text { Dense }\end{array}$ & $\begin{array}{l}t \\
+t \\
+t+\end{array}$ \\
\hline Left lobe & \multicolumn{5}{|c|}{ Light-coloured liver } \\
\hline $\begin{array}{l}\text { End } \\
\text { Middle } \\
\text { Base }\end{array}$ & $\begin{array}{l}56.0 \\
63.1 \\
43.5\end{array}$ & $\begin{array}{l}232 \\
210 \\
465\end{array}$ & $\begin{array}{l}130 \\
132 \\
202\end{array}$ & $\begin{array}{l}\text { Coarse } \\
\text { Coarse } \\
\text { Dense }\end{array}$ & $\overline{-}$ \\
\hline Central lobe & 48.1 & 465 & 223 & Dense & + \\
\hline $\begin{array}{l}\text { Right lobe } \\
\text { End } \\
\text { Middle } \\
\text { Base }\end{array}$ & $\begin{array}{l}60.2 \\
61.0 \\
49.0\end{array}$ & $\begin{array}{l}210 \\
230 \\
350\end{array}$ & $\begin{array}{l}126 \\
140 \\
172\end{array}$ & $\begin{array}{l}\text { Coarse } \\
\text { Coarse } \\
\text { Dense }\end{array}$ & $\overline{-}$ \\
\hline
\end{tabular}

green color with GDH reagent as shown in Fig. 2.

As can be seen from the Figure, much vitamin A is seen to co-exist with fat in micro-particles in the mucous membrane of the pyloric caeca and intestine of the oil sole. Observing the microparticles of fat component stained by GDH more in detail, three types of oil particles are noticed, one showing bright bluish green color, and the other two being faint or not stained at all by the reagent. The bluish green color by GDH staining was the most intensive towards the absorption terminal of the mucous membrane, gradually diminishing towards circular muscle. It was closely in agreement with the results of Katsui (8) and Araki (9) who observed the pyloric caeca of the scomber and pollack.

Vitamin A of the Liver of Dog Fish - Frozen sections of the liver after fixation in 10 per cent formalin were moderately defatted by immersing successively in alcohol solutions of increasing concentrations $(70 \rightarrow 80 \rightarrow 90 \rightarrow 99$ per cent), followed by staining with GDH.

Microscopic observation revealed that the circumference of black spots which were dispersed in liver tissues of the dog fish were stained more deeply than other hepatic tissue. These black spots were ascertained to be melanin pigments which were decolorized by dipping in bromine water as long as 24 hours (13), but were not changed by diluted acid, alkali or lipid solvents.

The section defatted by heating with water also revealed a deep, blue color around melanin pigments when Carr-Price reagent was employed as an 
indicator for vitamin $\mathrm{A}$ in tissues as illustrated in Fig. 3.

It may therefore be said that vitamin A exists much more densely in the melanin pigments than in other hepatic cells of the dog fish.

\section{DISCUSSION}

Defatting liver sections of the dog fish by immersing in absolute alcohol for 15,30 and 60 minutes, respectively, the manner of staining with GDH reagent differs according to the length of time. In 15 minutes, both the hepatic cells and melanin pigments are stained into bluish-purple color. In $30 \mathrm{mi}^{-}$ nutes, melanin pigments alone are stained leaving hepatic cells unstained.

Taking these facts into consideration, the following explanation seems to be feasible. At a range of 15 minute immersion, the extracting effect of alcohol can not break down the affinity of vitamin A to both melanin pigments and hepatic cells, while at 30 minute immersion, the extracting effect of alcohol overcomes the affinity of vitamin A to hepatic cells, and yet it can not break down the affinity of vitamin A to melanins. It is thus recognized that there are steps in the affinity of vitamin A to the components constituting liver tissues. The affinity of vitamin A to melanin pigments seems to be much stronger than that to hepatic cells.

From these experiments it may be assumed that vitamin A exists in an adsorbed state on melanin pigments; accordingly, it can hardly be extracted by alcohol, hence it is stained with GDH reagent. On the other hand, the vitamin A which is in contact with hepatic cells, may be more easily liberated when the liver was merely heated with water or treated with a weak lipid solvent such as alcohol. The vitamin A united with melanin pigments can only be completely liberated by repeated extractions with a much stronger lipid solvent such as ether. These findings suggest that the association between vitamin $\mathrm{A}$ and tissue componentsin cluding melanins is not so strong as that of chemical combination. When liver tissues are heated with water, the networks of lattice fibres retaining oil globules are broken down by autolysis providing a state favorable for oil globules to spread out easily of the hepatic cells. And yet, a good deal of vitamin A molecules may remain in the boundary of tissue protein (especially melanin pigments) and liver oil.

This may explain the following facts in the case of dog fish liver containing a large amount of melanin pigments :

The liver oil liberated by heating is poor in vitamin A, that liberated by pressing is richer in the vitamin and that extracted by ether from the residue is the richest in the vitamin.

The above mentioned tendency is very distinct in dog fish liver, but is scarcely detectable in pollack liver (14), possibly due to the fact that little melanin pigments exist in pollack liver as can be ascertained by microscopy.

Melanin is supposed to be a much more adsorptive matter than any components of hepatic cells and vitamin $\mathrm{A}$ has also a strong adsorptive power as it possesses five conjugated double bonds in a molecule. Therefore, it may not be accidental that the reaction of GDH for vitamin A occurs more strongly 
around melanin pigments in shark liver.

\section{SUMMARY}

1. A microscopic survey was carried out on the morphology of tissues and the existing state of fat substances in several kinds of fish containing much vitamin A.

2. The lean tissue consists of compact protein substances in which microparticles of lipoids are dispersed, but the fatty tissue is composed of lattice fibres consisting of coarse protein substances, among the lattice fibres of which a good deal of oil is contained.

3. The differences of the amount of vitamin A per $g$ of tissue of several kinds of fish and organs are less than those of the amount of vitamin A per $\mathrm{g}$ of oil.

4. It was elucidated that vitamin A co-existed opulently with fat component in micro-particles in the mucous membrane of pyloric caeca of the oil sole as seen in frozen sections stained by the osmium-GDH method.

5. It was found that vitamin A existed in association with melanin pigments which are dispersed in liver tissues of the dog fish and other sharks, as can be demonstrated when their frozen sections are stained with osmiumGDH reagents after moderate defatting with absolute alcohol.

\section{ACKNOWLEDGEMENTS}

The author wishes to express his hearty thanks to Professor Yasuhiko Tsuchiya, the Department of Fisheries, Faculty of Agriculture, Tohoku University for cordial suggestions, and Professor Sekio Mitsui, Department of Applied Science, Faculty of Engineering, Tohoku University, for valuable advices and also to Mr. Kan Takada, chief of the Chiganoura Laboratory of Nippon Reizo and Co. Ltd., who gave great convenience for preparing tissue sections and also to Dr. Kinosuke Kimura, Director of the Tohoku Regional Fisheries Research Laboratory and Dr. Kiyoshi Tanii, person in charge of the Department of Utilization of Marine Products of the same Laboratory for deep understanding and encouragement rendered to the author.

\section{REFERENCES}

1. Querner, F., and Sturm, K., Anat. Anz. 78, 289 (1934) ; Querner, F., Klin. Wochschr. 14, 1213 (1935).

2. Hirt, A., and Wimmer, K., Klin. Wochschr. 18, 733 (1940) ; ibid. 19, 123 (1940).

3. Wimmer, K., Ver. Anat. Ges. 47, 42 (1939).

4. Popper, H., J. Mt. Sinai Hosp. N. Y. 7, 119 (1940).

5. Joyet- Lavergne, P., C. $r$. Acad. Sic. 199, 1159 (1934)； 200, 346 (1935) ; 201, $1042(1935)$

6. Feinstein, L., J. Biol. Chem. 159, 569 (1945). 
7. Sobel, A. E., and Werbin, H., ibid. 159, 681 (1945).

8. Katsui, G., Vitamins 1, 374 (1948).

9. Araki, M., ibid. 5, 541 (1952).

10. Mori, I., The Theory and Method of Histological Chemistry (Japanese). Nanzando, Tokyo (1948).

11. Fujita, A., and Aoyama, M., Vitamins 4, 127 (1951).

12. Ishizawa, M., Text-book of Histology (Japanese). Vol. 1, 5th editon, p. 133 and 139 (1954).

13. Lison, L., Histochemie et Cytochimie Animals. Princepes et Methodes. (Translated into Japanese). p. 403, Hakusuisha, Tokyo (1954).

14. Kawai, K., and Yoshida, M., Yakugaku-Zasshi 53, 152 (1933). 